\title{
Pemanfaatan Media Filter Kearifan Lokal dalam Meningkatkan Kualitas Air dengan Proses Filtrasi
}

\author{
G.M Saragih ${ }^{1}$, Hadrah ${ }^{1 *}$, dan Herman ${ }^{2}$ \\ Fakultas Teknik Universitas Batanghari \\ *Correspondence email: hadrah.hasan@gmail.com
}

\begin{abstract}
The need for clean water continues to increase with changing times and the passage of time, however, clean water that is suitable for consumption is not easily available in some areas, considering that the physical conditions of regional geomorphology and hydrology have different forms. Water that is suitable for drinking must be clean and minimal from pollutant loads and substances that can interfere with the health of the body, this is different from the water obtained by people in Rantau Karya Village, Geragai District, Tanjung Jabung Timur Regency, because the hydrological conditions of the area are dominated by peatlands so that the water consumed is included in peat water, where the majority of the people use dug well water, therefore a simple technology is needed in dug well water treatment by utilizing local wisdom filter media. The results showed the efficiency of removal of organic substances (KMnO4) where the initial parameter was $22.5 \mathrm{mg} / \mathrm{l}$ to be $11.218 \mathrm{mg} / \mathrm{l}$. The efficiency of turbidity reduction is 56\%, where the initial result of the turbidity parameter is $31 \mathrm{NTU}$ and the final result is $15 \mathrm{NTU}$, and the final $\mathrm{pH}$ of well water is 6.26, where the initial test shows the number 5.6. Each thickness of the filter media to get optimum results with a thickness of $15 \mathrm{~cm}$.
\end{abstract}

Keywords: Dug Well, Filter Media, Local Wisdom.

\section{Pendahuluan}

Kebutuhan akan air bersih bagi manusia terus meningkat seiring dengan perkembangan zaman dan teknologi. Air bersih merupakan kebutuhan pokok yang tidak dapat dipisahkan dari kehidupan manusia, sehingga ketersediannya amatlah penting. Pemanfaatannya tidak hanya terbatas untuk keperluan rumah tangga, tetapi juga untuk fasilitas umum, sosial maupun ekonomi. Begitu pentingnya air bersih bagi kehidupan manusia, sehingga memungkinkan penyediaan menjadi terbatas bila pemanfaatannya tidak diatur dengan baik (eprints.polsri.ac.id,2019).

Bagi masyarakat perkotaan air bersih dapat disediakan dari pihak pengelola penyedia air bersih seperti PDAM, akan tetapi untuk daerah pedesaan atau daerah terpencil air yang digunakan biasanya berasal dari anak sungai, sumur gali, dan air hujan dimana kualitas dan kuantitasnya belum teruji secara pasti. Salah satu contoh daerah yang belum adanya penyediaan air bersih yaitu di Desa Rantau Karya Dusun Sukorejo Kecamatan Geragai, Kabupaten Tanjung Jabung Timur.

Masyarakat di Desa ini mayoritas masih menggunakan sumur gali untuk memenuhi kebutuhan sanitasi seperti mandi, cuci, dan keperluan toilet, sedangkan untuk air minum diperoleh dari air isi ulang depot air minum terdekat. Minimnya teknologi untuk pengolahan air, menyebabkan penduduk sekitar desa yang menggunakan air sumur gali, memiliki kualitas parameter kekeruhan yang tinggi.

Hasil uji laboratorium saat pra-penelitian diperoleh parameter $\mathrm{pH}$ sebesar 5,6, kekeruhan sebesar $31 \mathrm{NTU}$, dan Zat organik $\left(\mathrm{KMnO}_{4}\right)$ sebesar $25,2 \mathrm{mg} / \mathrm{L}$. Rendahnya $\mathrm{pH}$ air ini disebabkan oleh lapisan tanah Desa Rantau Karya Dusun Sukorejo yaitu merupakan tanah gambut dan gambut lempung, warna air sumurnya juga berwarna kuning serta mengandung besi ( $\mathrm{Fe})$, Mangan $(\mathrm{Mn})$, dan Kesadahan $\left(\mathrm{CaCo}_{3}\right)$. Kearifan lokal yang ada didaerah ini sungguh beragam mulai dari luasnya lahan gambut, pertanian yang didominasi tanaman kelapa, dan berdekatan dengan daerah pesisir pantai, yang banyak terdapat kerang laut. Dari uraian diatas maka penelitian ini diberijudul "Pemanfaatan Media Filter Kearifan Lokal Dalam Menurunkan Parameter Air Sumur Gali dengan
Proses Filtrasi (Studi Kasus : Desa Rantau Karya Dusun Sukorejo Kecamatan Geragai, Kabupaten Tanjung Jabung Timur)".

\section{Metode Penelitian}

\subsection{Persiapan Alat dan Bahan}

a. Alat

Bahan baku dalam penelitian ini adalah air sumur gali dari warga sekitar, yang diambil di Desa Rantau Karya Dusun Sukorejo, Kecamatan Geragai, Kabupaten Tanjung Jabung Timur, dan di bawah ke Laboratorium Dinas Lingkungan Hidup, Provinsi Jambi, untuk pengecekan $\mathrm{pH}$, kekeruhan,warna,Fe,Mn, $\mathrm{CaCO}_{3}$, Total Coliform, E. Coli, zat oganik $\left(\mathrm{KmnO}_{4}\right)$.

Unit Alat Filtrasi yang terbuat dari tabung dengan diameter 4 inch. Botol atau jerigen sebagai tempat penampung air sumur gali yang akan diuji kualitas dan kuantitas airnya. Drum plastik atau ember cat bersih, sebagai wadah penampungan sementara air sumur gali.

b. Bahan

Filtrasi yang digunakan dengan Down Flow, sedangkan media penyaring dalam penelitian ini terdiri dari bahan pasir halus, zeolit, arang batok kelapa, sabut kelapa, kulit kerang.

1) Pasir, sebagai penyaringan awal dalam proses penyaringan air, digunakan untuk menyaring partikel seperti pasir dan lumpur yang terlarut dalam air sehingga mengurangi kekeruhan air, rencana pemakaian media yang digunakan setinggi 5,10,dan $15 \mathrm{~cm}$;

2) Sabut Kelapa, media filter ini berfungsi sebagai penyaring partikel halus yang terdapat pada kandungan air yang lolos pada tahap media filter sebelumnya, digunakan untuk membatasi masing-masing media filter direncanakan pemakaian dengan tinggi $5 \mathrm{~cm}$;

3) Arang Batok, sebagai penyaringan untuk menghilangkan bau yang terdapat didalam kandungan air, dimana ketinggian media pada saat masing-masing pengujian yaitu 5,10 , dan $15 \mathrm{~cm}$.

4) Kulit kerang, sebagai penyaringan tahap akhir untuk menyaring partikel atau koloid yang masih tersisa pada 
saat penyaringan, masing-masing ketinggian media pada saat pengujian yaitu 5,10 , dan $15 \mathrm{~cm}$;

5) Zeolit, merupakan mineral yang dapat mengadsorbsi berbagai variasi logam berat maupun amonia, dan mampu memurnikan air.Masing-masing ketinggian media pada saat pengujian yaitu 5,10 , dan $15 \mathrm{~cm}$.

\subsection{Pelaksanaan Pekerjaan}

a. Pengambilan Sampel Air Sumur Gali

Sampel air yang digunakan adalah air sumur Gali yang berada di Desa Rantau Karya Dusun Sukorejo, Kecamatan Geragai, Kabupaten Tanjung Jabung Timur, lokasi tersebut merupakan salah-satu lahan gambut yang ada di Provinsi Jambi. Sampel air sumur gali yang diambil sebanyak 30 liter dengan menggunakan jerigen 30 liter.

\section{b. Analisis Parameter Sampel Air Sumur Gali}

Hasil setelah filtrasi diuji kembali di Laboratorium Dinas Lingkungan Hidup, Provinsi Jambi. Perlu diperhatikan pencatatan jumlah air baku yang diolah, waktu filtrasi, dan kurva dari hasil filtrasi yang dibandingkan dengan baku mutu tersebut,berapakah kemampuan masing-masing ketinggian yang diuji dari media tersebut sehingga didapat efisiensi dalam pengolahan air sumur gali.

c. Analisis Data

Pembahasan data yaitu dilakukan dengan membuat statistik yaitu berupa tabel dan grafik, dan dibahas secara deskritif kuantitatis.

\section{Hasil dan Pembahasan}

\subsection{Pembuatan Filter}

Alat filtrasi yang digunanakan dalam penelitian ini mengunakan sistem downflow rapid sand filter, sedangkan bahan baku media filter diambil berdasarkan kearifan lokal wilayah yang menjadi lokasi penelitian. Alat filtrasi terbuat dari pipa dengan ukuran 4" inch dengan ketinggian 1,5 m. Sedangkan media filter berupa pasir, sabut kelapa, arang batok kelapa, kulit kerang. Media filter diuji coba dengan masingmasing ketinggian $5 \mathrm{~cm}, 10 \mathrm{~cm}$, dan $15 \mathrm{~cm}$, terhadap air baku sumur gali, yang kemudian ditampung dalam wadah berukuran 1 liter.

Kecepatan penyaringan dicatat dengan menghitung waktu menggunakan stopwatch, berapa lama waktu penyaringan yang dapat ditampung dalam wadah berukuran 1 liter, pada masing-masing ketinggian media, dimana uji awal memiliki ketinggian $5 \mathrm{~cm}$ pada masing-masing media filter, 10 $\mathrm{cm}$, dan $15 \mathrm{~cm}$. Unit alat filtrasi beserta susunan media dapat dilihat pada gambar dibawah berikut.

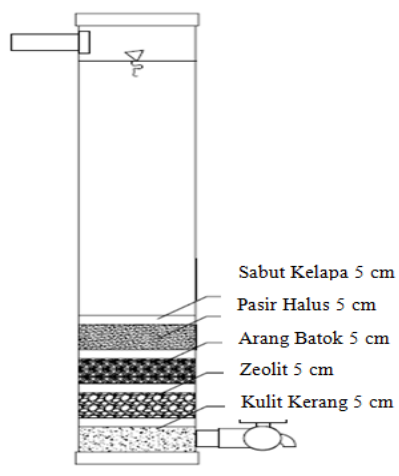

Gambar 1 Unit Filtrasi Ukuran Ketebalan Media Filter $5 \mathrm{~cm}$
Unit filtrasi dengan ukuran masing-masing media filter yang memiliki ketebalan $5 \mathrm{~cm}$, didapat perhitungan kecepatan pengolahan dengan debit 0,021 1/detik.

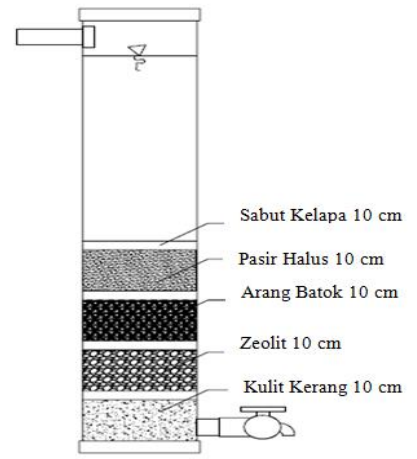

Gambar 2 Unit Filtrasi Ukuran Ketebalan Media Filter $10 \mathrm{~cm}$

Unit filtrasi dengan ukuran masing-masing media filter yang memiliki ketebalan $10 \mathrm{~cm}$, didapat perhitungan kecepatan pengolahan dengan debit 0,023 1/detik.

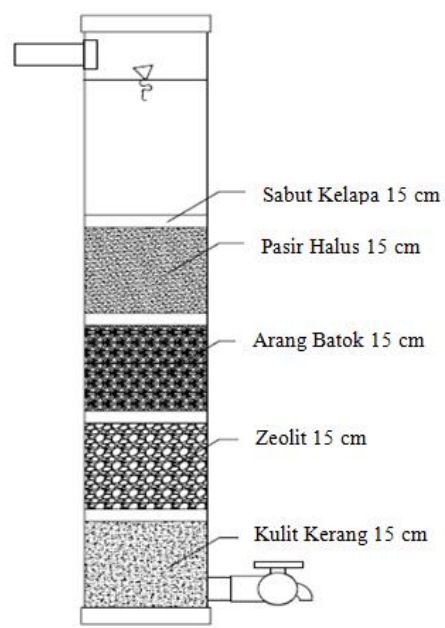

Gambar 3 Unit Filtrasi Ukuran Ketebalan Media Filter $15 \mathrm{~cm}$

Unit filtrasi dengan ukuran masing-masing media filter yang memiliki ketebalan $15 \mathrm{~cm}$, didapat perhitungan kecepatan pengolahan dengan debit 0,031 1/detik.

Pengujian pada alat filtarsi dilakukan secara bergantian dimulai dengan ukuran ketebalan $5 \mathrm{~cm}$, pada pengujian kedua $10 \mathrm{~cm}$ dan pada pengujian ketiga $15 \mathrm{~cm}$, pada masing-masing media filter dan dibatasi dengan sabut kelapa dengan ketebalan media $5 \mathrm{~cm}$. Debit air dihitung dengan cara menampung air yang telah dilakukan filtrasi, kemudian dihitung dengan stopwatch hingga penuh mencapai 1 liter, setelah itu waktu yang terhitung dibagi selama 60 detik maka didapat debit kecepatan untul liter/detik. Hubungan pemananfaatan media filter yang didapatkan dari kearifan lokal akan dijelaskan dalam hasil dan pembahasan berikut.

\section{Hasil Penelitian}

Berdasarkan penelitian yang dilakukan pada alat filtrasi sistem downflow atau saringan pasir cepat dengan pengujian sampel air baku dari air sumur gali milik warga sekitar Desa Rantau Karya, diketahui terjadi perubahan kualitas air baku dengan penambahan media filter dari kearifan lokal yang berada disekitar lokasi penelitian. Media filter terdiri dari arang dari batok kelapa, pasir halus, sabut kelapa, kulit kerang, 
dan zeolit. Sampel difilter dengan 3 kali pengujian menggunakan variasi debit yaitu 0,021 1/detik, 0,023 1/detik, dan $0,031 \mathrm{l} /$ detik. Pengujian awal dilakukan untuk mengetahui parameter kekeruhan, $\mathrm{pH}$, dan Zat Organik (KMnO4). Pengujian sampel dilakukan di Laboratorium Dinas Lingkungan Hidup Provinsi Jambi pada air sumur gali di Desa Rantau Karya.

Hasil pengujian dari ketiga standar baku mutu tersebut menunjukan hasil yang sama pada parameter yang tidak sesuai standar yang berlaku, maka dalam penelitian ini dilakukan uji coba pada media filtrasi dari kearifan lokal untuk menurunkan parameter seperti Zat Organik $\left(\mathrm{KMnO}_{4}\right)$, dan Kekeruhan, agar sesuai dengan standar baku mutu.

\section{Pengaruh Variasi Ketebalan Media dan Debit Terhadap pH}

Proses pengolahan dengan metode filtrasi downflow terdiri dari media arang batok kelapa sabut kelapa dengan ketebalan masing-masing $5 \mathrm{~cm}$, pasir halus, kulit kerang dan zeolit 5. Masing-masing media filter pada uji awal memiliki ketebalan media $5 \mathrm{~cm}, 10 \mathrm{~cm}$, dan $15 \mathrm{~cm}$. Sementara debit yang dialirkan dari proses filtrasi yaitu ukuran $5 \mathrm{~cm} \mathrm{0,031}$ liter/detik, $10 \mathrm{~cm} \mathrm{0,023} \mathrm{liter/detik,} \mathrm{dan} 15 \mathrm{~cm} \mathrm{0,021} \mathrm{liter/detik.}$

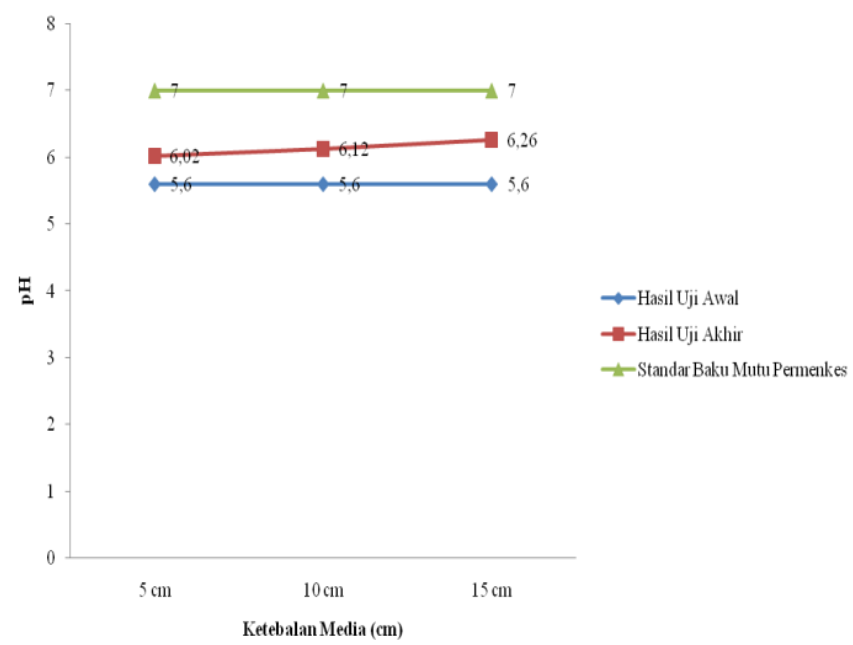

Gambar 4 Grafik Hasil Uji Filtrasi Air Sumur Gali Parameter $\mathrm{pH}$

Baku mutu rata-rata berdasarkan peraturan untuk $\mathrm{pH}$ adalah 6,5-8,5, sedangkan uji awal air sumur gali menunjukan angka dibawah standar mutu yaitu 5,6. Setelah dilakukan filtrasi terhadap media filter dengan ukuran ketebalan $5 \mathrm{~cm}$ didapatkan hasil uji pada sumur gali memiliki kualitas baku mutu yang mendekati standar peraturan yaitu sebesar 6,02 . Hasil tersebut menunjukan peningkatan kadar $\mathrm{pH}$ menjadi $8 \%$ dan juga pada ketebalan media filter ukuran $10 \mathrm{~cm}$, sedangkan ukuran ketebalan media $15 \mathrm{~cm}$, meningkat sebesar $10 \%$ pada air sumur gali, akan tetapi masih dibawah baku mutu yang disyaratkan.

Berdasarkan eksperimen yang dilakukan, hasil persentase penurunan diatas dimana semakain tebal media filter, dan semakain lama debit yang keluar dari alat filtrasi maka $\mathrm{pH}$ air dapat menjadi atau mendekati angka netral, hal tersebut dipengaruhi oleh media penyaring seperti pasir yang mampu mengikat partikel dan mengandung mineral yang dapat mengubah tingkat keasaman air.

Sedangkang kulit kerang yang mampu menjernihkan air disebabkan tingginya kalsium karbonat, bahkan mampu untuk mengurangi kadar Besi (Fe), dan Mangan (Mn). Sabut kelapa juga berfungsi untuk pengganti media kapas dan dapat memfilter material padatan yang lebih kecil.

Kemampuan arang aktif juga dapat mengubah tingkat keasaman air dari $\mathrm{pH}$ rendah menjadi lebih meningkat. Kemampuan zeolit dalam menghilangkan partikel-partikel disebabkan permukaannya dapat mengikat ion yang tinggi, sehingga fungsinya mampu menyerap senyawa organik dan logam berat, menstabilkan $\mathrm{pH}$, dan mencegah tumbuhnya algae, sehingga air tersebut layak dimanfaatkan oleh manusia.

\section{Pengaruh Variasi Ketebalan Media dan Debit Terhadap Zat Organik $\left(\mathrm{KMnO}_{4}\right)$}

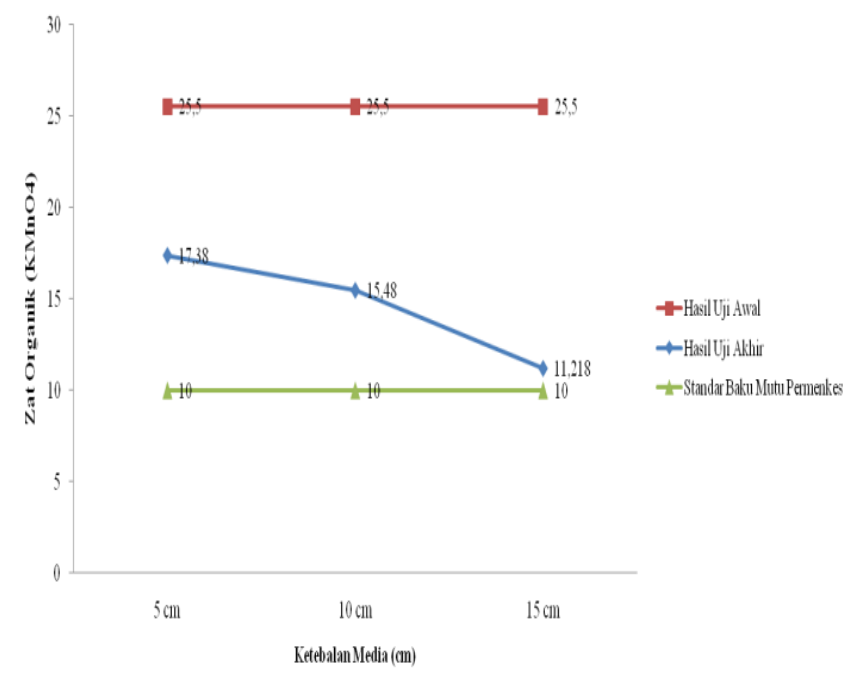

Gambar 5 Grafik Hasil Uji Filtrasi Air Sumur Gali Parameter Zat Organik (KMnO4)

Baku mutu rata-rata berdasarkan PERMENKES untuk zat organik (KMnO4) adalah $10 \mathrm{mg} / \mathrm{l}$, sedangkan uji awal air sumur gali menunjukan angka diatas standar mutu yaitu 25,5 $\mathrm{mg} / \mathrm{l}$. Setelah dilakukan filtrasi air sumur gali dengan media filter, dengan ketinggian $5 \mathrm{~cm}$ dan kecepatan 0,031 1/detik, nilai parameter zat organik yaitu sebesar $17,38 \mathrm{mg} / \mathrm{l}$, pada ketinggian filter $10 \mathrm{~cm}$ dan debit 0,023 1/detik nilai parameter zat organik sebesar $15,48 \mathrm{mg} / \mathrm{l}$, dan pada ketinggian media filter $15 \mathrm{~cm}$ dengan debit $0,021 \mathrm{l} /$ detik, nilai parameter zat organik sebesar $11,218 \mathrm{mg} / \mathrm{l}$, persentase penurunan yang terjadi pada ketebalan media $5 \mathrm{~cm}$ yaitu sebesar $32 \%$ dari hasil uji awal, ketebalan media $10 \mathrm{~cm}$ sebesar 39\%, dan ketebalan $15 \mathrm{~cm}$ sebesar $56 \%$.

Efisiensi penurunan tertinggi terjadi pada ketebalan media filter $10 \mathrm{~cm}$, akan tetapi hasil tersebut masih diatas baku mutu yang disyaratkan. Penelitian sebelumnya yang dilakukan oleh Usman, R, dkk, (2017). Pengolahan air baku dari sumur gali menggunakan teknologi boisand filter dual media terdiri dari media batu apung, dan pasir kuarsa mampu menurunkan zat organik pada ketinggian media $30 \mathrm{~cm}$, dengan efisiensi $71,48 \%$, dimana parameter awal zat organik $133 \mathrm{mg} / \mathrm{l}$ menjadi $10 \mathrm{mg} / \mathrm{l}$.

Pengaruh Variasi Ketebalan Media dan Debit Terhadap Kekeruhan 


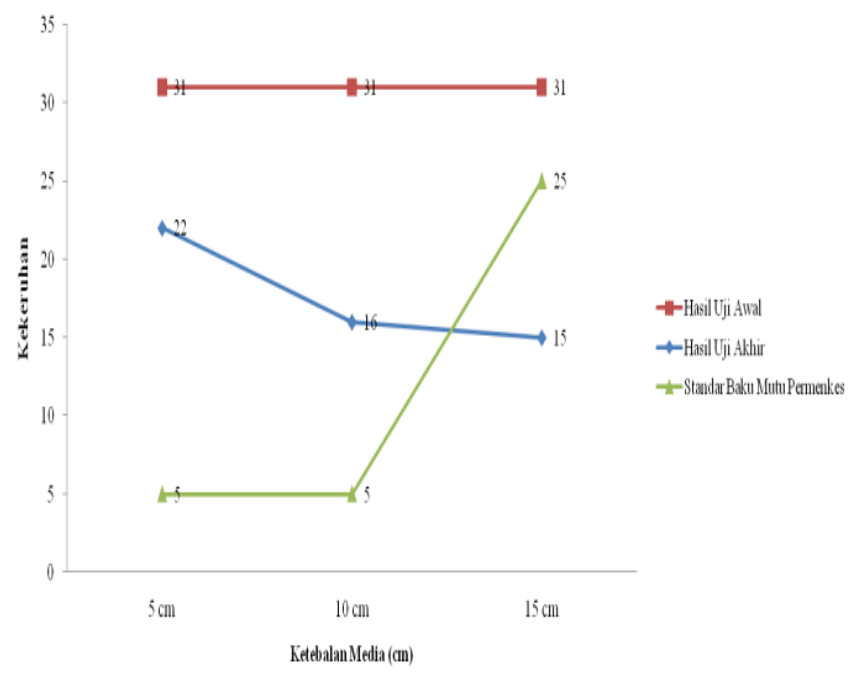

Gambar.6 Grafik Hasil Uji Filtrasi Air Sumur Gali Parameter Kekeruhan

Pengujian media filter berdasarkan grafik perbandingan diatas diketahui bahwa parameter berdasarkan PERMENKES Nomor 32 Tahun 2017. Baku mutu rata-rata berdasarkan peraturan tersebut untuk kekeruhan adalah 5 NTU dan untuk higien sanitasi yaitu 25 NTU, sedangkan uji awal air sumur gali menunjukan angka diatas standar mutu yaitu 31 NTU. Setelah dilakukan filtrasi air sumur gali dengan media filter, hasil uji pada sumur gali memiliki kualitas baku mutu pada media filtrasi dengan ketinggian $15 \mathrm{~cm}$ dan kecepatan 0,021 1/detik yaitu sebesar 15 NTU, ketinggian $10 \mathrm{~cm}$ dan debit $0,023 \mathrm{l} /$ detik sebesar $16 \mathrm{NTU}$, dan $5 \mathrm{~cm}$ dengan debit 0,031 1/detik sebesar 22 NTU. Persentase penurunan yang terjadi pada ketebalan media $15 \mathrm{~cm}$ yaitu sebesar $56 \%$ dari hasil uji awal, ketebalan media $10 \mathrm{~cm}$ sebesar $48 \%$, dan ketebalan $5 \mathrm{~cm}$ sebesar 29\%. Efisiensi penurunan tertinggi terjadi pada ketebalan media filter $15 \mathrm{~cm}$, akan tetapi hasil tersebut masih diatas baku mutu yang disyaratkan dengan persentase kualitas belum memenuhi standar sebesar 67\%, untuk keperluan air minum, sedangkan untuk higien sanitasi memenuhi standar baku mutu.

Berdasarkan eksperimen yang dilakukan, hasil persentase penurunan diatas dimana semakain tebal media filter, dan semakain lama debit yang keluar dari alat filtrasi maka semakin kecil kekeruhan akhir air sumur gali. Hal tersebut dipengaruhi oleh media penyaring seperti pasir yang mampu mengikat partikel kecil, disebabkan ukuran mesh dari pasir halus didaerah penelitian sangat kecil, menyebabkan partikelpartikel suspended solid menjadi tertahan.

Sedangkang kulit kerang mampu menjernihkan air disebabkan tingginya kalsium karbonat, dan juga mampu untuk mengurangi kadar Besi (Fe), dan Mangan (Mn).

Sabut kelapa yang merupakan limbah dari hasil pertanian dapat dimanfaatkan sebagai media filter. Pemanfaatan Sabut kelapa sebagai media filter juga berfungsi untuk pengganti media kapas dan dapat memfilter material padatan yang lebih kecil.

Sedangkan arang aktif didapat dari limbah cangkang kelapa dari industri pertanian kelapa. Kemampuan arang aktif juga dapat mengubah tingkat keasaman air dari $\mathrm{pH}$ rendah menjadi lebih meningkat.

Zeolit merupakan media tambahan dimana kemampuan zeolit dalam menghilangkan partikel-partikel disebabkan permukaannya dapat mengikat ion yang tinggi, sehingga fungsinya mampu menyerap senyawa organik dan logam berat, menstabilkan $\mathrm{pH}$, dan mencegah tumbuhnya algae, sehingga air tersebut layak dimanfaatkan oleh manusia

\section{Perbandingan Berdasarkan Baku Mutu}

Hasil uji dari laboratorium Dinas Lingkungan Hidup Provinsi Jambi, menunjukan hasil uji sampel air sumur gali dengan menggunakan media filter terdiri dari arang batok kelapa, sabut kelapa, pasir halus, kulit kerang, dan zeolit, menunjukan hasil penurunan tertinggi pada ketinggian media filter $15 \mathrm{~cm}$, untuk menurunkan parameter kekeruhan dan zat organik (KMnO4), setelah dilakukan proses filtrasi.

Petunjuk berdasarkan Standar Baku Mutu PERMENKES/32/2017, masih diatas standar baku mutu yang ditetapkan, akan tetapi cukup mendekati standar sebagai kualitas pemenuhan higien sanitasi bagi masyarakat. Sehingga dalam pengujian tersebut air sumur gali di Desa Rantau Karya, Dusun Sukorejo Kecamatan Geragai, Kabupaten Tanjung Jabung Timur, cukup untuk memenuhi standar untuk keperluan higien sanitasi, khusus untuk pemenuhan kebutuhan air minum, perlu dilakukan pengolahan lebih lanjut.

\section{Hubungan Media Filter}

Masing-masing media filter yang digunakan didapat dari keberadaan kearifan lokal setempat seperti arang pasir halus, batok kelapa, sabut kelapa, dan kulit kerang, pada pengujian awal dengan ketinggian media filter masing-masing $5 \mathrm{~cm}$ dapat meningkatkan parameter $\mathrm{pH}$ dari 5,6 menjadi 6,02, sedangkan media filter dengan ketebalan $5 \mathrm{~cm}$ dapat menurunkan zat organik (KMnO4) dari 25,2 mg/l menjadi $17,38 \mathrm{mg} / \mathrm{l}$, dan untuk parameter kekeruhan ketebalan media yang diuji $5 \mathrm{~cm}$ mampu menurunkan parameter kekeruhan dari 31 NTU menjadi 22 NTU.

Ketebalan media $10 \mathrm{~cm}$ dapat menaikan parameter $\mathrm{pH}$ pengujian awal sebesar 5,6 menjadi 6,12 , zat organik pengujian awal sebesar $25,2 \mathrm{mg} / \mathrm{l}$ menjadi $15,48 \mathrm{mg} / \mathrm{l}$, dan parameter kekeruhan dari 31 NTU menjadi 16 NTU.

Pengujian terakhir dengan alat filtrasi dimana ketebalan media filter masing-masing $15 \mathrm{~cm}$ dibatasi dengan sabut kelapa dengan ketebalan $5 \mathrm{~cm}$, dimana parameter $\mathrm{pH}$ dari pengujian awal sebesar 5,6 menjadi 6,26, parameter zat organik (KMnO4) menjadi dari pengujian awal 25,5 mg/l, menjadi $11,218 \mathrm{mg} / \mathrm{l}$, dan parameter kekeruhan pengujian awal sebesar 31 NTU menjadi 15 NTU.

Hasil pengujian diatas didapat kesimpulan dari masing-masing media filter, ukuran ketebalan media dan debit, dimana semakin tebal media filter dan debit air yang keluar lebih sedikit lama, maka hal tersebut dapat mempengaruhi penurunan dari beberapa parameter pencemar sehingga dapat menyesuaikan dengan baku mutu yang berlaku.

\section{Kesimpulan}

a. Terjadi perubahan parameter kualitas air padakekeruhan, zat organik $\left(\mathrm{KMnO}_{4}\right)$, dan $\mathrm{pH}$ air sumur gali setelah melalui proses filtrasi dengan media sabut kelapa, pasir halus, arang batok kelapa, zeolit, dan kulit kerang, dimana semakin tebal media filter dan semakin lama debit pengaliran maka dapat mempengaruhi perubahan pada masing-masing parameter beban pencemar. Akan tetapi parameter uji akhir belum memenuhi standar baku mutu, sehingga perlu dilakukan pengolahan lebih lanjut,

b. Uji awal yang dilakukan pada parameterr warna, Fe, $\mathrm{CaCO}_{3}$ sudah memenuhi standar baku mutu maka tidak 
dilakukan pemeriksaan kualitas setelah dilakukan filtrasi; Efisiensi penyisihan zat organik $\left(\mathrm{KMnO}_{4}\right)$, berdasarkan variasi ketebalan media filter 5,10 , dan $15 \mathrm{~cm}$ secara berurutan adalah $32 \%, 39 \%$, dan $56 \%$. Hasil akhir kandungan zat organik $\left(\mathrm{KMnO}_{4}\right)$. sebesar 11,218 mg/l; Efisiensi penurunan kekeruhan, dengan ketebalan media filter $5 \mathrm{~cm}$ memiliki efisiensi pengurangan $29 \%$, ketebalan media $10 \mathrm{~cm}$ sebesar $48 \%$, dan ketebalan $15 \mathrm{~cm}$ sebesar $56 \%$, hasil akhir sebesar 15 NTU, dimana hasil awal parameter kekeruhan sebesar 31 NTU; pH akhir air sumur sebesar 6,26, dimana uji awal menunjukan angka 5,6.

\section{Daftar Pustaka}

Anonymous. (2016) BAB II Tinjauan Pustaka Filtrasi. dipetik pada tanggal 17 Juni 2020, dari repository.ipb.ac.id. https://repository.ipb.ac.id/jspui/bitstream/123456789/6 8392/4/BAB\%20II\%20 Tinjauan\%20Pustaka.pdf

Indrawati,D .(2016). Tinjauan Pustaka BAB II. dipetik pada tanggal 17 Juni 2020 dari :http://eprints.undip.ac.id/53577/4/BAB_II_62.pdf

Lathifa.L,. (2017). BAB II Tinjauan Pustaka Pengertian Air. dipetik pada tanggal 15 Juni 2020, dari repository.unimus.ac.id http://repository.unimus.ac.id/400/3/BAB\%20II.pdf

Merda.EP,.dkk (2014). Makalah utilitas dan sumber air baku. dipetik pada tanggal 20 Juni 2020, dari anonimhttp://library.binus.ac.id/eColls/eThesisdoc/Bab 2/2014-2-02348 SP\%20Bab2002.pdf

Peraturan Menteri Kesehatan Republik Indonesia Nomor 416 Tentang Syarat-syarat Dan Pengawasan Kualitas Air Tahun 1990.

Peraturan Menteri Kesehatan Republik IndonesiaNomor 492 Tahun 2010 Tentang Persyaratan Kualitas Air Minum.

Permen Kesehatan Nomor 32 Tahun 2017 Tentang Standar Baku Mutu Kesehatan Lingkungan Persyaratan Kesehatan Air Untuk Keperluan Higienis Sanitasi Kolam Renang Solus Per Aqua.

Septiyanti.A,. (2016). BAB II Pengertian Ari Baku . dipetik pada tanggal 15 Juni 2020, dari eprints.polsri.ac.id.http://eprints.polsri.ac.id/3388/3/3. \%20Bab\%20II.pdf

Siringoringo. C.F. (2019). BAB II Tinjauan Pustaka Filtrasi. dipetik pada tanggal 17 Juni 2020, dari eprints.undip.ac.id. http://eprints.undip.ac.id/76891/6/8._BAB_II.pdf

Zahra.I,.(2014). Saringan Pasir Lambat Paling Lengkap. Dipetik pada tangga 15 Juli 2020, dari http://digilib.unimus.ac.id/files/disk1/104/jtptunimusgdl-laelanurch-5154-3-bab2.pdf

Aprian.R,.(2017). Filtrasi. dipetik pada tanggal 18 Oktober 2020 http://eprints.uny.ac.id/30252/3/BAB\%202.pdf 